\title{
A peptide derived from alpha-fetoprotein inhibits the proliferation induced by estradiol in mammary tumor cells in culture
}

\author{
WALTER D. SIERRALTA ${ }^{1}$, MARíA J. EPUÑAN ${ }^{1}$, JOSÉ M. REYES ${ }^{3}$, LUIS E. VALLADARES ${ }^{2}$, \\ THOMAS T. ANDERSEN ${ }^{4}$, JAMES A. BENNETT ${ }^{4}$, HERBERT I. JACOBSON ${ }^{4}$ and ANA M. PINO ${ }^{1}$ \\ Laboratorios de ${ }^{1}$ Ultrastructuras and ${ }^{2}$ Hormonas y Receptores, INTA-Universidad de Chile, Avda. Macul 5540, \\ Santiago 7830489; ${ }^{3}$ Centro de Oncología, Clínica Las Condes, Lo Fontecilla 454, Las Condes, Chile; \\ ${ }^{4}$ Center for Cardiovascular Sciences and Department of Obstetrics, Gynecology and Reproductive Sciences, \\ Albany Medical College MC-16, 47 New Scotland Ave, Albany, NY 12208, USA
}

Received May 29, 2007; Accepted July 25, 2007

\begin{abstract}
This study was aimed to obtain additional information on the activity of a cyclized 9-amino acid peptide (cP) containing the active site of alpha fetoprotein, which inhibits the estrogen-stimulated proliferation of tumor cells in culture and of xenografts in immunodeficient mice. Breast cancer cells cultured in the presence of $2 \mathrm{nM}$ estradiol were exposed to $\mathrm{cP}$ for different periods and their proliferation, estradiol binding parameters, clustering tendency and expression of E-cadherin and p21Cip1 were analyzed by biochemical and cell biology methods. The proliferation of MCF7 cells was significantly decreased by the addition of $2 \mu \mathrm{g} / \mathrm{ml} \mathrm{cP}$ to the medium. cP did not increase cell death rate nor alter the number of binding sites for estradiol nor the endogenous aromatase activity of MCF7 cells. cP also decreased the proliferation of estrogen-dependent ZR75-1 cells but had no effect on estrogen-independent MDA-MB-231 cells. An increased nuclear p21Cip1 expression detected after cP treatment suggests that $\mathrm{cP}$ slows $\mathrm{MCF} 7$ cell proliferation via this regulator. We propose that $\mathrm{cP}$ could represent a novel breast cancer therapeutic agent whose mechanism of action is different from that of tamoxifen or of inhibitors of aromatase.
\end{abstract}

\section{Introduction}

The most common cancer in women worldwide affects the mammary gland, a tissue composed of highly-sensitive target

Correspondence to: Dr Walter D. Sierralta, Laboratorio de Ultrastructuras, INTA-Universidad de Chile, Avda. Macul 5540, Santiago 7830489, Chile

E-mail:wsierra@uchile.cl

Key words: alpha fetoprotein, estradiol-dependent proliferation, mammary tumor cells, p21Cip1, antiproliferative peptide, active cyclic nonapeptide, inhibition of cell growth cells for estradiol that contain the estradiol receptors $\alpha$ and $B$ (ER $\alpha, E R ß)$ (1). These receptors bind to estrogen-response elements in the promoter region of cognate target genes, or interact with proteins in other pathways to regulate the transcription of specific genes in estrogen-dependent cells (2-6). Estradiol has a proliferative effect on breast cancer cells, regulating the biosynthesis of some growth factors (7-9), of growth factor receptors and of other signaling molecules (10). In addition, estradiol can activate phosphatidylinositol-3-kinase and mitogen-activated protein kinase pathways (11-13).

Several studies indicate that estrogen action can induce and promote breast cancer; therefore, decreasing estrogen production by aromatase inhibitors or blocking its action with antiestrogens have been the main treatments for ER $\alpha$ positive tumors $(14,15)$.

Little is known about the physiological role of alphafetoprotein (AFP), a glycoprotein produced mainly by the fetal liver (16) and thought to play a protecting role for the offspring during fetal and perinatal development. Recent studies in mice demonstrate that AFP prevents entry of estrogens in developing brain, facilitating the normal development of the female fetal brain (17). From epidemiologic studies on pregnancy-associated protection against breast cancer, Jacobson et al hypothesized that AFP acts in an endocrine manner to extinguish premalignant foci in pregnant women (18). Jacobson et al also reported that AFP exerts antiestrogenic effects on breast cancer growth in rodent models (19) and, more recently, identified the active site of AFP responsible for this activity $(20,21)$. The same investigators have synthesized a cyclized 9-mer AFP-active site analog, cycloEMTOVNOGQ (cP). This peptide remains very stable during long-term storage and, like AFP, has the ability to inhibit estradiol-stimulated growth of estrogen-dependent human breast cancer xenografts growing in severe combined immunodeficient (SCID) mice and to hinder the estrogen-stimulated growth of the uterus in immature animals (22). Furthermore, in vivo administration of the whole AFP molecule or the $\mathrm{cP}$ had no effect on estradiol circulating levels in rodents $(22,23)$. 
Much of what is known about the mitogenic actions of estrogen in ER-positive tumors has come from the study of hormone action in human breast cancer cells. Mammary tumor cells like wild-type MCF7, T47D and ZR75-1 proliferate faster when estradiol is present in the culture medium, evidencing their sensitivity towards the steroid. The simultaneous addition of an estradiol-interfering molecule to this system usually causes a reduction in the cell proliferation rate. Besides increased cell death rate, the most probable causes of reduced proliferation by the presence of a drug are specific alterations in the progress of the cell cycle, or a generalized slowing-down leading to cell senescence. Progression through the cell cycle is controlled by the coordinated activity of distinct cyclin-dependent kinases (CDKs) (24). CDKs are negatively regulated by two classes of CDK inhibitors (CKIs), namely the CIP/KIP and the INK4 families of proteins. Among the CIP/KIP proteins, p21Cip1 is considered a central regulator of the cell cycle (25). In addition, p21Cip1 participates in the control of other cell proccesses, regulated by a variety of stimuli including senescence, genome damage, serum starvation and differentiation (26).

The aim of this study was to study the inhibitory effect of $\mathrm{cP}$ on growth of mammary tumor cells in culture. We report the effect of the AFP-derived cyclic peptide on the proliferation, clustering tendency and p21Cip1 expression of MCF7 cells cultured in the presence and absence of estradiol.

\section{Materials and methods}

Materials. The AFP-derived nonapeptide cyclo (EKTOVNOGN) (where O is hydroxyproline) and a control scrambled peptide were obtained by solid-phase peptide synthesis using $\mathrm{N}$-(9-fluorenyl)methoxycarbonyl, as already described (22). Tissue culture materials, PVDF membranes and Precision Plus Protein Standards were purchased from NalgeNunc (Rochester, NY, USA) and BioRad Laboratories (Hercules, CA, USA), respectively. 2,4,6,7-tritium labeled estradiol was purchased from NEN Life Science Division of Perkin-Elmer (Boston, MA, USA). The following antibodies were from Santa Cruz Biotechnology, Inc. (Santa Cruz, CA, USA) antiE-cadherin murine monoclonal antibody (sc8426); antip21Cip1 rabbit polyclonal antibody (sc756) and FITCconjugated goat anti-mouse IgG (sc2010). AlexaFluor-488 conjugated donkey anti-rabbit IgG (A21206) was purchased from Molecular Probes-Invitrogen Corp. (Carlsbad, CA, USA).

Cell lines. Estradiol-sensitive MCF7 epithelial cells established from human metastasic breast cancer tissue (HTB 22; ATCC, USA), were cultured in MEM-Eagle media containing $10 \%$ calf serum, $1 \mathrm{mM}$ sodium pyruvate, $2 \mathrm{mM}$ L-glutamine and antibiotics. The estradiol-sensitive human breast carcinoma cell line ZR75-1 (CRL 1500; ATCC, USA), was cultured in RPMI-1640 medium adjusted to $2 \mathrm{mM}$ L-glutamine, $1.5 \mathrm{~g} / \mathrm{l}$ sodium bicarbonate, $4.5 \mathrm{~g} / 1$ glucose, $10 \mathrm{mM}$ HEPES, and $1 \mathrm{mM}$ sodium pyruvate and containing $10 \%$ calf serum and antibiotics. The estradiol-insensitive cell line MDA-MB231 (HTB-26; ATCC, USA), used for control studies, was cultured in D-MEM/F12 mixture (1:1) containing bicarbonate, $10 \%$ calf serum and antibiotics. Charcoal dextran-stripped calf serum (CDSS) was used in all cases, to reduce the content of endogenous estradiol in calf serum (27); calf serum was used to avoid the presence of alpha fetoprotein. Cells were incubated at $37^{\circ} \mathrm{C}$ in a humidified incubator, in a $5 \% \mathrm{CO}_{2}$ atmosphere.

Proliferation studies. MCF7 (12,000 cells/ $\left.\mathrm{cm}^{2}\right)$, ZR75-1 $\left(16,000\right.$ cells $\left./ \mathrm{cm}^{2}\right)$, and MDA-MB231 $\left(6,000\right.$ cells $\left./ \mathrm{cm}^{2}\right)$, were seeded and incubated for $24 \mathrm{~h}$. After cells became attached to the culture vessel, non-adherent cells and media were removed. The adherent cells were reincubated with the respective culture medium containing either $2 \mathrm{nM}$ estradiol or $2 \mu \mathrm{g} / \mathrm{ml}$ of cyclic peptide for various periods of time, with a change of culture medium every $48 \mathrm{~h}$. For all cell lines, parallel control experiments in the absence of estradiol or cyclic peptide or in the presence of a scrambled peptide were perfomed. All experiments were done in triplicate.

At the completion of the incubation period, cells were washed with phosphate-buffered saline (PBS), detached ( $0.25 \%$ trypsin in $0.2 \mathrm{mM}$ EDTA), resuspended in PBS, counted and assessed for viability (trypan blue).

Doubling time measurements. Doubling times were determined from growth curves of MCF7 cells inoculated at $\mathrm{t}_{0}$ at a density of 10,000 cells $/ \mathrm{cm}^{2}$. Cell counts were measured in triplicate in a haemocytometer every $24 \mathrm{~h}$ for up to $120 \mathrm{~h}$. The counts were plotted on a log scale and fitted to a straight line by linear regression.

Cell cycle studies. For these studies, MCF7 cells $(10,000$ cells/ $\mathrm{cm}^{2}$ ) were seeded in B25 bottles; once attached the cells were serum deprived for $24 \mathrm{~h}$. Synchronized cells were then incubated with culture medium containing $2 \mathrm{nM}$ estradiol with or without $2 \mu \mathrm{g} / \mathrm{ml}$ of the cyclic peptide. At defined time periods, cell aliquots were labeled with propidium iodide (PI, $10 \mathrm{mg} / \mathrm{ml})$, treated with RNAse A $(300 \mu \mathrm{g} / \mathrm{ml})$ and their DNA content analyzed by the ModFit LTTM software (Becton-Dickinson, CA, USA) using a FACScaliber (Becton-Dickinson).

Immunofluorescence studies. Cells exposed to different experimental conditions were grown on sterile coverglass and then fixed (methanol, $20 \mathrm{~min}$ at $-20^{\circ} \mathrm{C}$ ), rinsed (PBS containing $2 \% \mathrm{BSA})$ and incubated with the primary antibodies (1 $\mathrm{h}$ at RT). After extensive washes (PBS containing 2\% BSA), cells were incubated with the appropriate secondary antibody and nuclei counterstained with Hoechst 33240. After immunolabeling, cells were washed, mounted and viewed with a Zeiss Axiophot epifluorescence microscope fitted with a color CCD camera.

Western blot analysis. For total cell protein extraction, cells were sonicated in RIPA buffer $(0.5 \%$ deoxycholate, $1 \%$ SDS, $1 \%$ nonidet NP-40, $150 \mathrm{mM} \mathrm{NaCl}, 50 \mathrm{mM}$ Tris, $\mathrm{pH} 8.0$ ) containing PMSF (phenylmethylsulfonylfluoride) and complete protease inhibitor cocktail. For SDS/PAGE, $40 \mu \mathrm{g}$ protein samples were incubated for $5 \mathrm{~min}$ at $95^{\circ} \mathrm{C}$ and loaded in $10 \%$ polyacrylamide gels. Electrophoresis was performed at RT for $1 \mathrm{~h}$ at $100 \mathrm{~V}$ using BioRad Miniprotean chambers. 
A

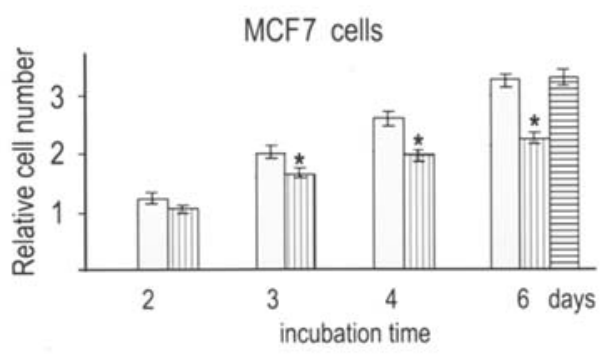

B

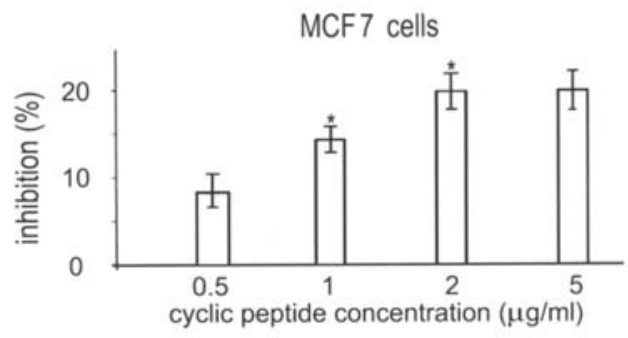

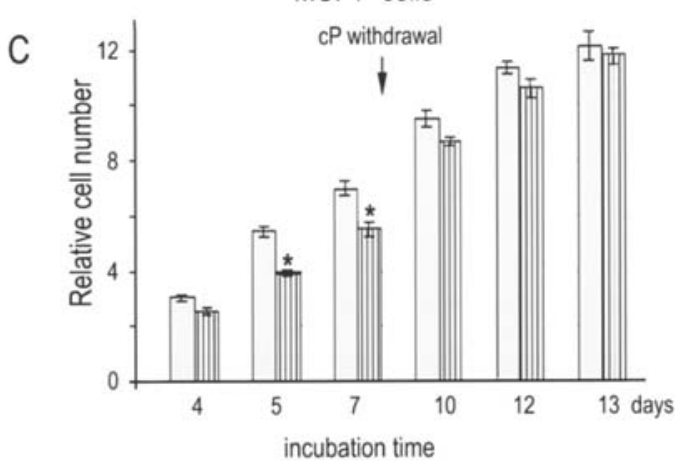

D

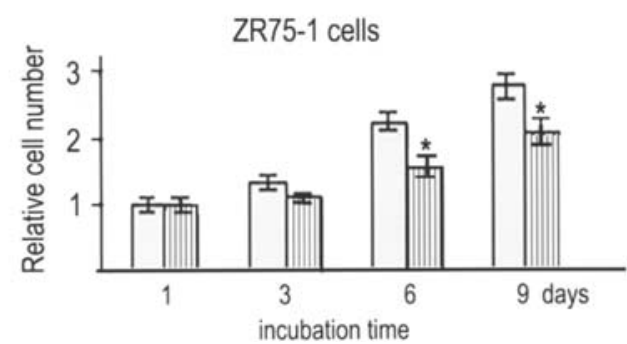

$\mathrm{E}$

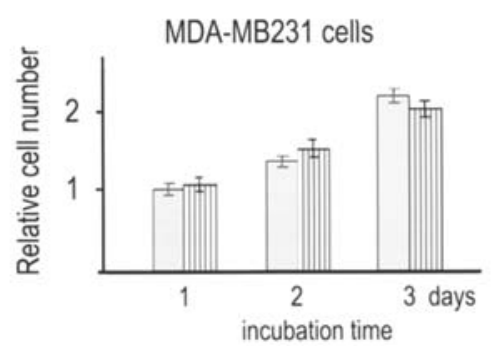

Figure 1. Effect of $\mathrm{cP}$ on estradiol-stimulated proliferation of mammary tumor cells in culture. (A) Depicts proliferation of MCF7 cells in the presence of 2 nM estradiol alone (grey bars); in the presence of $2 \mathrm{nM}$ estradiol and $2 \mu \mathrm{g} / \mathrm{ml} \mathrm{cP}$ (vertically hatched bars) or in the presence of estradiol and $2 \mu \mathrm{g} / \mathrm{ml} \mathrm{scrambled}$ peptide (horizontally hatched bar). Proliferation rate was expressed as a relative cell number calculated in relation to the cell number of control cells ( $24 \mathrm{~h}$ after seeding; 21,700 cells $/ \mathrm{cm}^{2}$ ), which was set to 1 . Values are mean $\pm \mathrm{SD}$ of 3 experiments in triplicate. *For differences between $\mathrm{cP}+\mathrm{E}_{2}$ vs $\mathrm{E}_{2}$, $\mathrm{p}<0.05$ at 3 , 4 and 6 days. (B) Depicts the changes in the proliferation (measured at day 4) of MCF7 cells incubated in the presence of 2 nM estradiol and increasing amounts of $\mathrm{cP}$. Values are mean $\pm \mathrm{SD}$ of 4 experiments. ${ }^{*}$ Significance of the inhibitory effect was observed when cP concentration was increased from 0.5 to $1 \mu \mathrm{g} / \mathrm{ml}$ and from 1 to $2 \mu \mathrm{g} / \mathrm{ml}\left(\mathrm{p}<0.05\right.$ ). (C) Depicts proliferation of MCF7 cells seeded at 1,000 cells/ $\mathrm{cm}^{2}$ (P6 plates) and cultured in the presence of $2 \mathrm{nM}$ estradiol (grey bars) and $2 \mathrm{nM}$ estradiol and $2 \mu \mathrm{g} / \mathrm{ml} \mathrm{cP}$ (hatched bars). The effect of $\mathrm{cP}$ removal at day 7 (arrow) is shown by the grey and hatched bars. Values are mean \pm $\mathrm{SD}$ of 3 experiments. *Significance of the inhibitory effect was observed at 5 and 7 days of cP action (p<0.05). (D) Displays the effects of estradiol and cP on proliferation of ZR75-1 cells. The cells were grown in RPMI-1640 medium with 5\% CDSS containing 2 nM estradiol (grey columns) or in medium containing $2 \mathrm{nM}$ estradiol plus $2 \mu \mathrm{g} / \mathrm{ml} \mathrm{cP}$ (hatched columns). Means $\pm \mathrm{SD}$ of 4 experiments. *For differences between $\mathrm{cP}+\mathrm{E}_{2} \mathrm{vs} \mathrm{E}_{2}, \mathrm{p}<0.05$ at 6 and 9 days. (E) Depicts the lack of response of MDA-MB-231 cells to $\mathrm{cP}$ addition: proliferation of cells in medium containing $5 \%$ calf serum in the absence (grey columns) or presence of $2 \mu \mathrm{g} / \mathrm{ml} \mathrm{cP}$ (hatched columns). Means $\pm \mathrm{SD}$ of 4 experiments. Not significant differences.

Bands were electro-transferred onto PVDF membranes and immunodetection was done by using the appropriate primary antibodies and peroxidase-labelled secondary antibodies. Bands were developed with DAB and hydrogen peroxide.

Statistical analyses. Student's t-test was used to evaluate differences between samples and the respective controls; $\mathrm{p}<0.05$ was considered significant. Data were analyzed with Statistica for Windows Software, release 6, Statsoft Inc., USA.

\section{Results}

Effect of the cyclized peptide $(c P)$ on the proliferation of mammary tumor cells. The effect of the $\mathrm{cP}$ on the proliferation rate of two estradiol-sensitive epithelial cell lines (MCF7 and ZR75-1) and the estradiol-insensitive cell line MDA-MB231, was studied at various conditions as indicated in Fig. 1.

Proliferation of the estradiol-dependent cell line MCF7 was inhibited after $\mathrm{cP}$ addition in the culture media, observing the maximal inhibitory effect $(\sim 40 \%)$ after 6 days (Fig. 1A). In addition, the inhibitory effect of $\mathrm{cP}$ was structure-dependent since the addition of a scrambled peptide $(2 \mu \mathrm{g} / \mathrm{ml})$ did not affect estrogen-dependent growth of these cells (Fig. 1A, day 6). The inhibitory effect of $\mathrm{cP}$ on MCF7 proliferation was dose-dependent and attained a maximum at $2 \mu \mathrm{g} / \mathrm{ml} \mathrm{cP}$ concentration (Fig. 1B). The effect was reversible since although a lag of $48 \mathrm{~h}$ followed after $\mathrm{cP}$ withdrawal from the medium, proliferation rate recovered allowing to come close to the cell number obtained under $2 \mathrm{nM}$ estradiol (Fig. 1C). Inhibition 

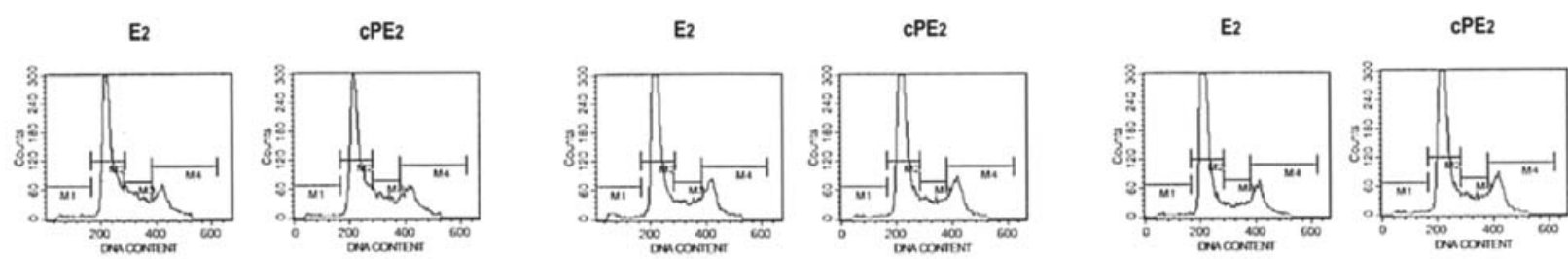

day 1

day 2
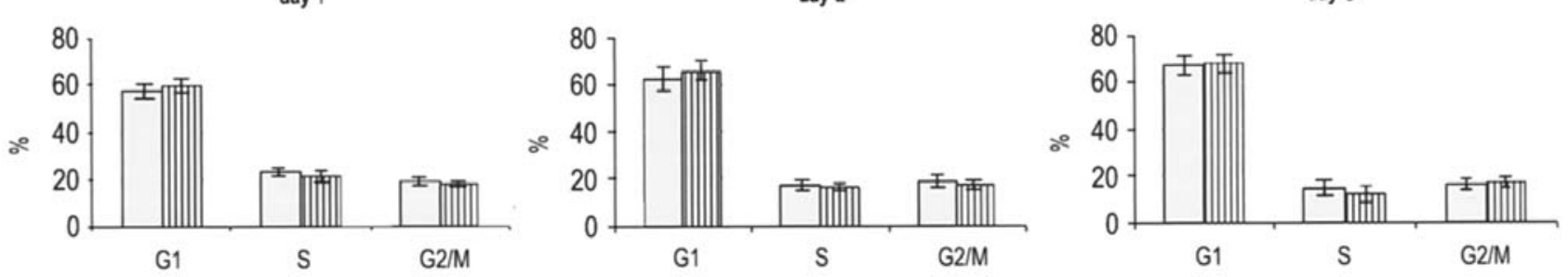

Figure 2. Cell cycle analysis of MCF7 after stimulation with $2 \mathrm{nM}$ estradiol in the presence or absence of $2 \mu \mathrm{g} / \mathrm{ml} \mathrm{cP}$. The results are presented as percentage of cells at each cell cycle stage. Means of 2 experiments \pm range. Each time-point panel contains a FacSort representative graph depicting the distribution frequency of cells for each sample. Codes for the areas: M1, apoptosis; M2, G0/G1; M3, S; M4, G2/M.

of proliferation by $\mathrm{cP}$ seems to be specific for the growth of estradiol-dependent cells: like MCF7 cells, the proliferation of the estradiol-sensitive human breast cancer ZR75-1 cells was also inhibited by cP (Fig. 1D). Conversely, the growth of estradiol-insensitive MDA-MB231 cells was unaffected by the presence of $\mathrm{cP}$ in the culture medium (Fig. 1E).

The inhibitory effect of $\mathrm{cP}$ on MCF7 proliferation is disclosed by the values of cell doubling time measured in the absence or in the presence of $\mathrm{cP}(2 \mu \mathrm{g} / \mathrm{ml})$, that increased from $52 \pm 2$ to $63 \pm 3 \mathrm{~h}$, respectively.

To assess whether the effect of $\mathrm{cP}$ on the estradiolstimulated cell proliferation could be associated to a change in the transition of cells through the cell cycle, the percentage of cells at each stage of the cell cycle was assessed by flow cytometry. Results in Fig. 2 showed no change in the percentage of cells at each phase of the cycle when MFC7 cells were cultured with estradiol in the presence or absence of $\mathrm{cP}$. In addition, under both conditions apoptotic cells were not detected, as shown by the lack of a sub-G0/G1 peak.

When MCF7 cells were seeded at mid cell density, cells grew as a mixture of large ( $\geq 20$ cells) and small ( $<20$ cells) clusters, tightly connected by strong cell-to-cell interactions (Fig. 3A). We investigated whether $\mathrm{cP}$ impaired cluster formation, analyzing the proportion of large and small cell clusters. We observed that the $\mathrm{cP}$ increased significantly the percentage of small clusters at the cost of the larger ones (Fig. 3B). Thus, the cP impaired the ability of MCF7 cells to grow and develop into large clusters.

Since growth of estradiol-sensitive breast cancer cells forming clusters and their aggressive behavior have been related to changes in E-cadherin expression (29), we analyzed E-cadherin expression by MCF7 cells grown both in the presence and absence of $\mathrm{cP}$. As shown, no change in Ecadherin immunostaining by cells was observed (Fig. 3C, D). Western blotting confirmed that the level of E-cadherin expression by these cells is not affected by $\mathrm{cP}$ (Fig. 3E).

On the other hand, the estradiol-insensitive cell line MDA-MB23, which proliferates as single rather than clustered cells, was not affected by $\mathrm{cP}$ (data not shown).
A

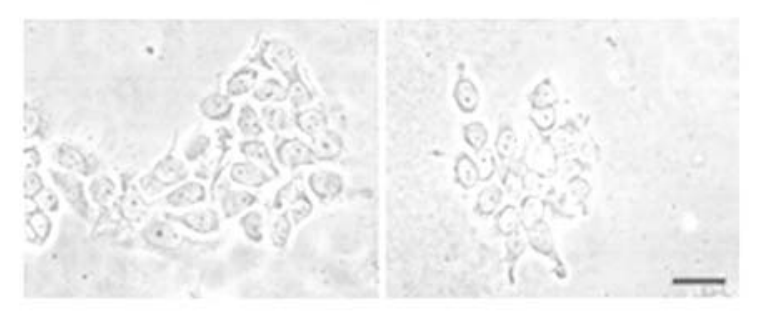

B
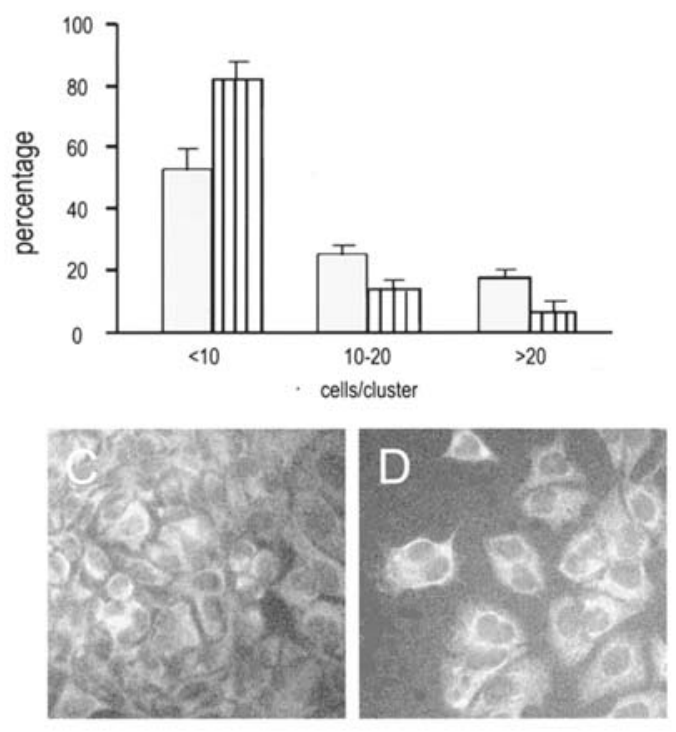

E

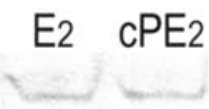

Figure 3. Tendency of MCF7 cells to form clusters. (A), Representative images of MCF7 growth in clusters in the presence of $2 \mathrm{nM}$ estradiol (left), and $2 \mathrm{nM}$ estradiol and $2 \mu \mathrm{g} / \mathrm{ml} \mathrm{cP}$ (right). The bar represents $100 \mu \mathrm{m}$. (B), Frequency of cluster sizes, after incubation MCF7 cells with $2 \mathrm{nM}$ estradiol (grey bar) and with $2 \mathrm{nM}$ estradiol plus $2 \mu \mathrm{g} / \mathrm{ml} \mathrm{cP}$ (hattched bar). Representative fluorescence images of MCF7 cells grown for $16 \mathrm{~h}$ in medium containing $10 \%$ CDSS in the presence of $2 \mathrm{nM}$ estradiol alone (C) or estradiol and $2 \mu \mathrm{g} / \mathrm{ml} \mathrm{cP}$ (D). Content of E-cadherin in MCF7 cells grown under estradiol alone $\left(\mathrm{E}_{2}\right)$ or plus $\mathrm{cP}\left(\mathrm{cPE}_{2}\right)$ is shown in the immunoblot $(\mathrm{E})$. 

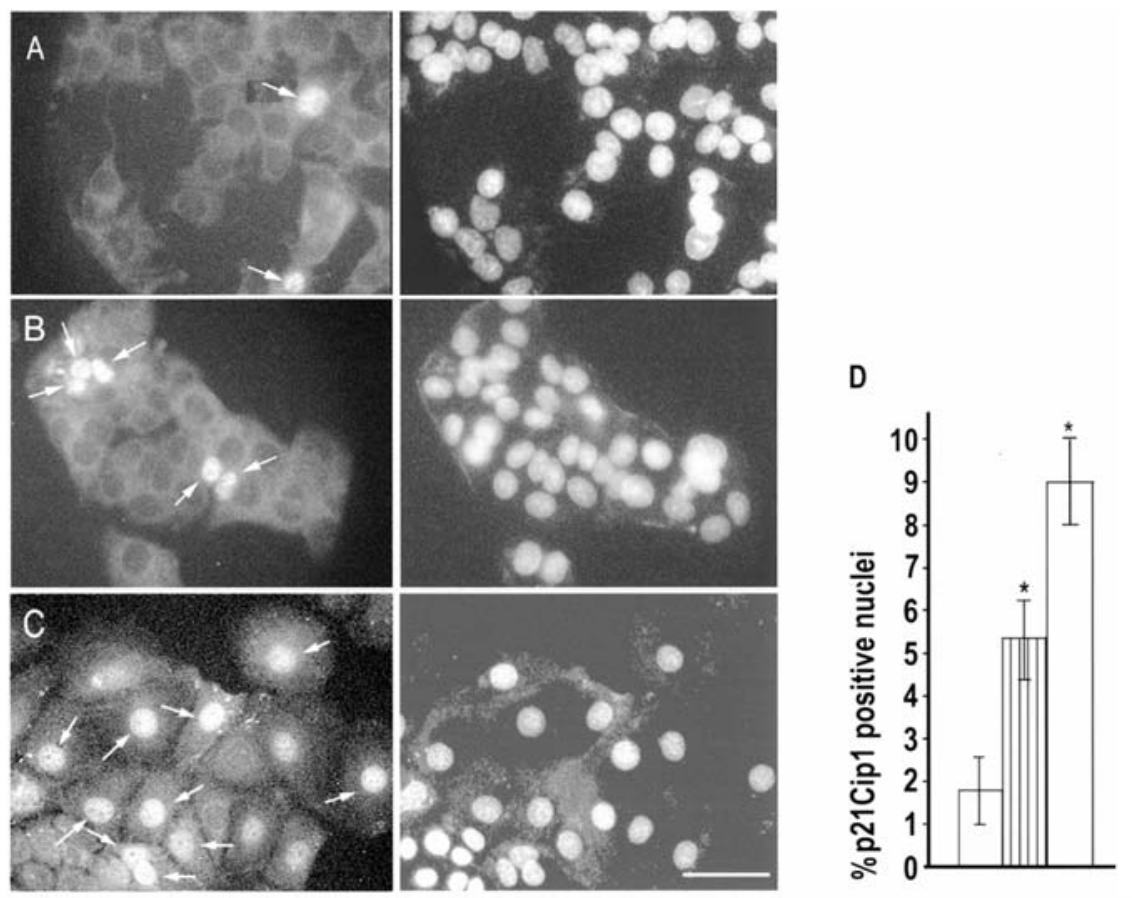

Figure 4. Immunofluorescence analysis of p21 in MCF7 cells. Cells were expossed for 16 h to media containing $5 \%$ CDSS plus 2 nM estradiol (A), or CDSS $+2 \mathrm{nM}$ estradiol $+2 \mu \mathrm{g} / \mathrm{ml} \mathrm{cP}(\mathrm{B})$ or CDSS $+2 \mu \mathrm{g} / \mathrm{ml} \mathrm{cP}(\mathrm{C})$. The left panel shows expression of p21Cip1 detected by immunofluorescence staining with FITC-labeled antibody in a representative field. The right side depicts all the nuclei present in the field (Hoechst-DNA staining). The arrows point to nuclear p21Cip1 positive cells; the bar represents $100 \mu \mathrm{m}$. The histogram (D) shows the percentage of MCF7 cells depicting nuclear p21Cip1 immunoreactivity after 16-h stimulation with estradiol in the absence of $\mathrm{cP}$ (grey bar) estradiol in the presence of $\mathrm{cP}$ (hatched bar) and $\mathrm{cP}$ alone (open bar). Mean $\pm \mathrm{SD}$ of 6 experiments in each of which 1240 nuclei in random microscope fields were inspected. *For the difference between $c \mathrm{P}+\mathrm{E}_{2} \mathrm{vs} \mathrm{E}_{2}$ and vs $\mathrm{cP}, \mathrm{p}<0.05$.

Cellular and molecular mechanisms involved in the action of $c P$ on the growth of estradiol-sensitive cells. The optimum growth of estradiol-sensitive epithelial cells in culture is known to depend on the concentration of estradiol and estradiol binding sites. Since, estradiol could be bound unspecifically by $\mathrm{cP}$ reducing the hormone availability, we measured direct in vitro binding capacity by incubating several tritium labeled estradiol concentrations with different amounts of the cP. Using the hydroxyapatite assay (28), we found that the $\mathrm{cP}$ does not bind free estradiol. In addition, Scatchard analyses confirmed that the $\mathrm{cP}$ did not modify the association constant nor the number of estradiol-binding sites in MCF7 cells: in the presence and absence of cP, the value of $\mathrm{Kd}(0.073 \pm 0.002 \mathrm{nM})$ as well as the number of binding sites per cell $(9,700 \pm 600)$ were maintained.

It has been proposed that in situ-production of estrogens plays an important role in the promotion of breast tumors (30). Some human breast cancer cells have enhanced expression of the enzyme aromatase, allowing the production of estrogens from circulating androgens. Therefore, we studied whether the presence of $\mathrm{cP}$ during incubation hindered a putative generation of estrogens from androgens by MCF7 cells. Cell proliferation was measured without estradiol but in the presence or absence $\mathrm{cP}$ and androstenedione or testosterone as aromatase substrates. Results demonstrated that, independent of the presence or absence of $\mathrm{cP}$, androgens did not significantly stimulate MCF7 cell proliferation. Furthermore, the propagation of these cells was not affected by addition of an aromatase inhibitor (data not shown).

Preclinical studies have shown that the treatment of breast cancer xenografts with $\mathrm{cP}$ induces the phosphorylation of p53, a major modulator of p21Cip1 (31). Therefore, we analyzed p21Cip1 immunostaining in MCF7 cells after exposure to $\mathrm{cP}(2 \mu \mathrm{g} / \mathrm{ml})$ in the presence or absence of estradiol $(2 \mathrm{nM})$. As shown in Fig. 4A, little localization of p21Cip1 was observed within the nuclei of estradiol-stimulated cells. In contrast, the simultaneous presence of $\mathrm{cP}$ and estradiol significantly increased the presence of p21Cip1 in nuclei (Fig. 4B). Moreover, in the absence of estradiol, cP caused increased p21Cip1 nuclear immunostaining (Fig. 4C). These observations are quantified and summarized in the Fig. 4D. The effect of the cP on p21Cip1 staining showed specific, since the scrambled peptide had no effect (data not shown).

\section{Discussion}

The effects of estrogens on target cells in culture are dependent on the experimental system employed (27). In our experiments, the proliferation of MCF7 cells increased 30-35\% under $2 \mathrm{nM}$ estradiol treatment in medium supplemented with CDSS, as compared to medium without the steroid. The addition of $\mathrm{cP}$, but not that of a scrambled peptide, reduced the estrogenstimulated growth of cells; the dose-response experiments showed that maximal effect was attained at $2 \mu \mathrm{g} / \mathrm{ml} \mathrm{cP}$ (Fig. 1). This effect of $\mathrm{cP}$ was reversible, since removal of the peptide from the medium allowed cells to recover. The $\mathrm{cP}$ also inhibited the estrogen-dependent growth of ZR75-1 cells but had no effect on MDA-MB231, a known estrogen-unresponsive cell line (Fig. 1). These results complement recent observations on the effect of $\mathrm{cP}$ on the growth of mammary tumor cell xenografts in severely combined immunodeficient mice (22). Results also demonstrate that the $\mathrm{cP}$ did not 
modify values of estradiol dissociation constant and number of binding sites in the MCF7 cells. Previous experiments have shown no interference of this peptide with estradiol binding to preparations enriched in estrogen receptor (23). Additionally, cP exhibited no effect on the endogenous generation of estradiol from androgens.

Comparisons of cell cycle progression between estradioland estradiol plus $\mathrm{cP}$ treated cells showed no apparent change in the percentage of cells at the G1, S and G2/M stages of the cell cycle. However, a significant reduction in the total number of cells was customarily observed. A similar situation in cell cycle progression (namely a transient multi-phase cell cycle arrest) has been reported in murine fibroblasts exposed to sub-lethal redox stress (32). FACSort analysis showed no change in the extent of cell apoptosis under $\mathrm{cP}$ and/or estradiol treatment and, in addition, light microscopy evaluation of fixed and hematoxylin-eosin-stained cells and immunoanalysis of active caspase 3 levels (data not shown) indicated that the presence of $\mathrm{cP}$ did not increase cell death. Thus, the reduced proliferation observed appears to be related with a generalized lengthening of the cell cycle. We conclude that the mechanism of action of $\mathrm{cP}$ is different from that of tamoxifen and other antiestrogens observed by Osborne et al (33).

Differences in the size of the clusters formed after $16 \mathrm{~h}$ of exposure to $\mathrm{cP}$ and/or estradiol were observed, suggesting that the treatments could affect inter-cell attraction. It has been reported that in MCF7 cells growing as clusters, a decrease of E-cadherin expression accompanies the loss of cellular contacts and seems to be associated with a diminished cell proliferation without the participation of apoptosis (34). Therefore we analyzed, by immunofluorescence and immunoblotting, the effect of $\mathrm{cP}$ on E-cadherin and found that the cyclic peptide did not induce changes in the expression of this protein, ruling out an effect of $\mathrm{cP}$ on this pathway of intercellular adhesion.

The protein p21Cip1 controls the cell cycle, sustained high levels of this inhibitor for prolonged time arrests growth of epithelial cells (35). In addition, other functions for p21Cip1 have been demonstrated, including regulation of transcription, protection from apoptosis and modulation of cell motility $(25,36)$, among others. Therefore, modulation of p21Cip1 expression or its function might be fundamental for regulation of the proliferative activity. In cultured mammary tumor cells, p21Cip1 is activated by both p53-dependent and independent mechanisms, and behaves as an estrogen-modulated protein (37). The low levels of p21Cip1 in wild-type MCF7 cells limited a quantitative assessment of $\mathrm{p} 21$ by immunoblotting (38). For this reason we used the sensitive but qualitative immunofluorescence analysis, that showed that $\mathrm{cP}$ affected nuclear p21Cip1 immunoreactivity of MCF7 cells depending on the presence or absence of estradiol. Cells exposed to estradiol showed low number of p21Cip1 immunostained nuclei. In cells treated with $\mathrm{cP}$ alone, the number of p21Cip1 stained nuclei increased significantly; but this effect was diminished when estradiol was also present in the medium. Our results show that $\mathrm{cP}$ promotes nuclear accumulation of p21Cip1 which could slow down cell proliferation. This observation supports results showing that $\mathrm{cP}$ hinders estrogenstimulated growth of human breast cancer xenografts (31). We conclude that $\mathrm{cP}$ could transiently remove an estradiol- dependent block on p21Cip1 expression, thus reducing the proliferative estradiol effect on MCF7 cells (39); alternatively, $\mathrm{cP}$ treatment might increase p21Cip1 gene expression. In any case, high levels of p21Cip1 would extend the proliferation time of MCF7 cells. Further studies are required to clarify these alternatives.

Summarizing, our results show that $\mathrm{cP}$ interferes with the estradiol-dependent proliferation of mammary cancer cells; the presence of $\mathrm{cP}$ increased nuclear p21Cip1 immunoreactivity, suggesting this as a probable site of action. Altogether, our observations support the idea that the cyclic nonapeptide (cP) derived from AFP, could represent a novel breast cancer therapeutic agent whose mechanism of action is different from that of drugs like tamoxifen and aromatase inhibitors (33).

\section{Acknowledgements}

This study was supported by Grant Nr 1040881 from Fondecyt Chile.

\section{References}

1. Sommer S and Fuqua SA: Oestrogen receptor and breast cancer. Semin Cancer Biol 11: 339-352, 2001.

2. Tsai M and O'Malley BW: Molecular mechanism of action of steroid/thyroid superfamily members. Annual Rev Biochem 63: 451-486, 1994.

3. Batistuzzo de Madeiros SR, Krey G, Hihi AK and Wahli W: Functional interaction between the estrogen receptor and the transcription factor $S p 1$ regulate the estrogen-dependent transcriptional activity of the vitellogenin A1 promoter. J Biol Chem 272: 18250-18260, 1997.

4. Galienand WJ and Garcia T: Estrogen receptor impairs interleukin- 6 expression by preventing protein binding on the NF-kappaB site. Nucleic Acids Res 25: 2424-2429, 1997.

5. Paech K, Webb P, Kuiper GG, Nilsson S, Gustafsson JA, Kushner PJ and Scalan TS: Differential ligand activation of estrogen receptors ERalpha and ERbeta at AP1 sites. Science 277: 1508-1510, 1997.

6. Porter W, Saville B, Hoivik D and Safe S: Functional synergy between the transcription factor $\mathrm{Sp} 1$ and the estrogen receptor. Mol Endocrinol 11: 1569-1580, 1999.

7. Knabbe C, Lippman ME, Wakefield LM, Flanders KC, Kasid A, Derynck R and Dickson RB: Evidence that transforming growth factor beta is a hormonally regulated negative growth factor in human breast cancer cells. Cell 48: 417-428, 1987.

8. Bates SE, Davidson NE, Valverius EM, et al: Expression of transforming growth factor-alpha and its messenger ribonucleic acid in human breast cancer: its regulation by estrogen and its posssible functional significance. Mol Endocrinol 2: 543-555, 1998.

9. Osborne KC, Schiff R, Fuqua SA and Shou J: Estrogen receptor: current understanding of its activation and modulation. Clin Cancer Res 7: S4338-S4342, 2001.

10. Huynh H, Yang X and Pollak M: Estradiol and antiestrogens regulate a growth inhibitory insulin-like growth factor binding protein 3 autocrine loop in human breast cancer cell. J Biol Chem 271: 1016-1021, 1996.

11. Kato S, Endoh H, Masuhiro Y, et al: Activation of the estrogen receptor through phosphorylation by mitogen-activated proteinkinase. Science 270: 1491-1494, 1995.

12. Simoncini T, Hafezi-Moghadam A, Brazil DP, Ley K, Chin WW and Liao JK: Interaction of estrogen receptor with the regulatory subunit of phophatidylinositol-3-OH kinase. Nature 407: 538-541, 2000.

13. Santen RJ, Song RX, MacPherson R, Kumar R, Adam L, Jeng $\mathrm{MH}$ and Yue W: The role of mitogen-activated protein (MAP) kinase in breast cancer. J Steroid Biochem Mol Biol 80: 239-256, 2002.

14. Santen RJ: To block estrogen's synthesis or action: that is the question. J Clin Endocrinol Metab 87: 3007-3012, 2002. 
15. Gradishar WJ and Jordan VC: Clinical potential of new antiestrogens. J Clin Oncol 15: 840-852, 1997.

16. Deutsch HF: Chemistry and biology of alpha-fetoprotein. Adv Cancer Res 56: 253-312, 1991.

17. Bakker J, De Mees C, Douhard Q, Balthazart J, Gabant P, Szpirer J and Szpirer C: Alpha-fetoprotein protects the developing female mouse brain from masculinization and defeminization by estrogens. Nature Neurosci 9: 220-226, 2006.

18. Jacobson HI, Thompson WD and Janerich DT: Multiple births and maternal risk of breast cancer. Amer J Epidemiol 129: 865-873, 1989.

19. Jacobson HI, Bennet JA and Mizejewski GJ: Inhibition of estrogen-dependent breast cancer growth by a reaction product of alpha-fetoprotein and estradiol. Cancer Res 50: 415-420, 1990.

20. Mesfin FB, Bennett JA, Jacobson HI, Zhu SJ and Andersen TT: Alpha-fetoprotein-derived antiestrotrophic octapeptide. Biochim Biophys Acta 1501: 33-43, 2000.

21. DeFreest LA, Mesfin FB, Joseph L, et al: Synthetic peptide derived from alpha-fetoprotein inhibits growth of human breast cancer: investigation of the pharmacophore and synthesis optimization. J Pept Res 63: 409-419, 2004.

22. Bennett JA, Mesfin FB, Andersen TT, Gierthy JF and Jacobson HI: A peptide derived from $\alpha$-fetoprotein prevents the growth of estrogen-dependent human breast cancers sensitive and resistant to tamoxifen. Proc Natl Acad Sci USA 99: 2211-2215, 2002.

23. Bennett JA, Zhu S, Pagano-Mirarchi A, Kellom TA and Jacobson HI: Alpha-fetoprotein derived from a human hepatoma prevents growth of estrogen-dependent human breast cancer xenografts. Clin Cancer Res 4: 2877-2884, 1998.

24. Sherr CJ and Roberts JM: CDK inhibitors: positive and negative regulators of G1-phase progression. Genes Dev 13: 1501-1512, 1999.

25. Coqueret O: New roles for $\mathrm{p} 21$ and $\mathrm{p} 27$ cell-cycle inhibitors: a function for each cell compartment? Trends Cell Biol 13: 65-70, 2003.

26. Dotto GP: p21(WAF1/Cip1): more than a break to the cell cycle? Biochim Biophys Acta 1471: M43-M56, 2000

27. Braunsberg H, Coldham NG and Leake RE: Effects of serum type on steroid receptor binding sites and response to progestin of cultured human breast cancer cells. Eur J Cancer Clin Oncol 23: 573-576, 1987.
28. Williams D and Gorski J: Equilibrium binding of estradiol by uterine cell suspensions and whole uteri in vitro. Biochemistry 13: $5537-5542,1974$

29. Hiscox S, Jiang WG, Obermeier K, et al: Tamoxifen resistance in MCF7 cells promotes EMT-like behaviour and involves modulation of beta-catenin phosphorylation. Int J Cancer 118: 290-301, 2006.

30. Chen S: Aromatase and breast cancer. Front Biosci 3: D922-D933, 1998.

31. Parikh RR, Gildener-Leapman N, Narendran A, et al: Prevention of n-methyl-N-nitrosourea-induced breast cancer by alpha-fetoprotein (AFP)-derived peptide, a peptide derived from the active site of AFP. Clin Cancer Res 11: 8512-8520, 2005.

32. Barnouin K, Dubuisson MI, Child ES, et al: $\mathrm{H} 2 \mathrm{O} 2$ induces a transient multi-phase cell cycle arrest in mouse fibroblasts through modulating cyclin D and p21Cip1 expression. J Biol Chem 277: 13761-13770, 2002

33. Osborne CK, Boldt DH and Estrada P: Human breast cancer cell cycle synchronization by estrogens and antiestrogens in culture. Cancer Res 44: 1433-1439, 1984.

34. Nasarre P, Kusy S, Constantin B, Castellani V, Drabkinz HA, Bagnard D and Roche J: Semaphorin SEMA3F has a repulsing activity on breast cancer cells and inhibits E-cadherin-mediated cell adhesion. Neoplasia 7: 180-189, 2005.

35. Nicolas FJ and Hill CS: Attenuation of the TGF-beta-Smad signaling pathway in pancreatic tumor cells confers resistance to TGF-beta-induced growth arrest. Oncogene 22: 3698-3711, 2003.

36. Planas-Silva MD and Weinberg RA: Estrogen-dependent cyclin E-cdk2 activation through p21 redistribution. Mol Cell Biol 17: 4059-4069, 1997.

37. Prives C and Hall PA: The p53 pathway. J Pathol 187: 112-126, 1999.

38. Margueron R, Licznar A, Lazennec G, Vignon F and Cavailles V: Oestrogen receptor $\alpha$ increases $\mathrm{p} 21^{\mathrm{WAF} / \mathrm{CP} 1}$ gene expression and the antiproliferative activity of histone acetylase inhibitors in human breast cancer cells. J Endocrinol 179: 41-53, 2003.

39. Lai A, Sarcevic B, Prall OWJ and Sutherland RL: Insulin/ insulin-like growth factor-I and estrogen cooperate to stimulate cyclin E-Cdk2 activation and cell cycle progression in MCF-7 breast cancer cells through differential regulation of cyclin $\mathrm{E}$ and p21WAF1/Cip1. J Biol Chem 276: 25823-25833, 2001. 